\title{
Waiting for Nothing: Nihilism, Doubt and Difference without Difference in Post-Revolutionary Georgia
}

\author{
Martin Demant Frederiksen
}

\section{Introduction}

In late 2015, a Tbilisi-based artist posts a statement online concerning an attack that had recently taken place in the capital of the Republic of Georgia against Campus Studio. This was a space where students, artists and architects had been meeting for a series of different events, including artist talks and discussions of a range of various theoretical texts and perspectives. The statement read as follows:

Since many of the lectures drew between 100 and 150 people, Campus Studio used loudspeakers, so that the audience could hear the lecture on the street and in the yard. During one of the lectures Nietzsche's quotation 'God is dead' could be heard on the streets. This apparently caused some of the neighbors to believe Campus Studio to be a meeting space for satanic gatherings, luring young adults and children. On November 15 three young adults from the neighborhood interrupted a lecture and one attacked co-founder and director Misha Khundadze with a knife. With serious lung injuries and blood loss, Misha survived after an extensive operation and days in intensive care. All this happened, once again, in the name of faith and religion. Not only has the Georgian Orthodox Church fueled hatred and ignorance, but the government has been looking away over the past when crimes in the name of Georgian Orthodoxy have been committed, ridiculing the secular aim manifested in the country's constitution (Concept and Theory - Tbilisi 2015).

The 'once again' in the text refers to a series of violent attacks having taken place in the Republic of Georgia in recent years against individuals or groups 
condemned by the Georgian Orthodox Church. Some of these were carried out in the name of the Church by fanatic followers, some were officially condoned by the Church, and some were carried out by orthodox priests themselves. ${ }^{1}$ For local clergy in Georgia, nihilist tendencies have long been seen as a highly problematic phenomena coinciding with other 'subcultures' not fitting into the worldview of the Church, and believed these to cause a serious moral problem for the country and its population. This stems from the perspective that believing in something lies at the very basis of what constitutes a human being; not believing, whether as an atheist or a nihilist, inevitably renders a person un-human ${ }^{2}$ and devoid of morality (Frederiksen 2015). Yet the people who had gathered in and around Campus Studio during the event that caused the attack were not necessarily either nihilists or satanists; they were simply discussing Nietzsche, as they had been discussing many other theorists.

My own original interest in nihilism in Georgia started some years prior to this event when Natia, an old friend living in Tbilisi, noted to me during a conversation that 'everyone I know is a nihilist'. We had originally been talking about atheism, but Natia assured me that when people were talking about no longer believing, about 'everything being nothing' (kvelaperi araperia) and about senses of disengagement, such statements were rarely directed against the Georgian Orthodox Church. Rather, she said, they were directed against local politics. And indeed, nihilism has been depicted by several local politicians themselves as being a major societal disease in contemporary Georgia (e.g. Chigoev 2011). When the formerly relatively unknown businessman Bidzina Ivanishvili entered Georgian politics in 2011 by launching the new opposition party 'Georgian Dream' (kartuli ots'neba), he declared that one of his reasons for doing so was that 'there is nihilism ingrained in [Georgian] people. With my appearance on the stage, people have hope' (Doward 2011). Particularly young people, it was held, were increasingly disengaging from social and political life. A decade earlier the so-called Rose Revolution had taken place in the country, ${ }^{3}$ and the question of youth disengagement was perceived as potentially threatening the democratic ideals and hopeful visions of a new future for the country originally underlying this revolution. These ideals entailed, among other things, the consolidation of civil society, eradication of corruption and strengthened ties to the EU and US, moves towards something believed to be both better than and different from the chaotic post-Soviet period of the 1990s where Georgia had been stumbling to find its feet as an independent nation. Yet, in the years following the revolution it soon became clear that many of these ideals either proved difficult to achieve in practice, or that they did not necessarily entail the 
changes envisioned as once achieved. This chapter explores how, in individual experiences, revolution and politics in Georgia have often come to be seen as the very opposite of such revolutionary ideals - namely as 'difference without difference'.

Religious fear of 'nothing' is not something particular to Georgia - it is a fear that has a long history in the wider world (Barrow 2001; Green 2011). Nor is political fear of nothing and nihilism something we find only here. Yet, it does seem to have had a heightened salience in Georgia in the period following the Rose Revolution in the sense that, as I will argue, politicians increasingly partook in creating their own horror: citizens who simply did not care, who saw changes as not entailing any difference, and who came to hold that there was nothing to wait for no matter how increasingly grand the promises made by politicians became. Focusing mainly on a group of self-declared nihilists, I discuss in the following pages what is entailed in the shift from waiting for something to waiting for nothing in particular. What is at stake, I ask, in the creation of a poetics of waiting without a telos? And what happens to the poetics of waiting when we displace our focus from looking at 'waiting for something to change' to looking at 'waiting for nothing to change'? I approach waiting here as a lack of narrative that may come to form a permanent present (Johnson-Hanks 2014). In the theoretical discussion of the questions posed above, I draw mainly on Mladen Dolar's reading of Samuel Beckett, an author for whom both 'nothing' and 'waiting' were central (if not the central) themes of his writings.

\section{A note on difference}

Before we enter the smoke-filled rooms of indifference that make up the empirical part of the chapter, I want to spend some time on the question of 'difference, which is of central importance to my overall discussion. For this I turn to a recent piece by Sarah Green in which she traces the epistemological logics of geographical borders and the rules for establishing a difference between a 'here' and a 'there'. Based on the case of two uninhabited Aegean islands and the dispute between Greece and Turkey about which country these islands belong to, Green notes that:

there are different ways of making sense of the meaning of the 'here' as opposed to 'elsewhere', and these methods often coexist in the same space. This simple condition - the coexistence of different border regimes, each of which uses a 
different logic to establish the meaning of places - inevitably makes grey zones, ambiguities and uncertainties at the interface between border regimes (Green 2015: 182).

What is at stake here is two different places coexisting within the same uninhabited geographical space. Under normal circumstances, this difference does not make a difference - the islands are more or less just a gathering of rocks in the sea that no one really pays attention to. But at one point a Turkish cargo ship ran aground on one of them and the captain subsequently refused the assistance of a Greek coastguard because the island, in the captain's perspective, was Turkish territory and it should therefore be the Turkish coastguard coming to assistance. Now, suddenly, the difference suddenly began to make a difference.

In her account, Green outlines a paradox of border-making; a situation where the drawing of borders, which is usually perceived as an act of creating clarity, ends up creating anything but clarity. In other words, rather than removing ambiguity of what is here and what is there, differences within epistemological logics underlying the making borders may end up as grey zones where 'heres' and 'theres' begin to intermingle or overlap. The overall question, then, is when does a difference begin to make a difference? (Green 2015: 175). And what is the role of doubt, along with related notions of temporality, waiting and crises of meaning, in the potential outcomes of this question?

What is at stake in the empirical context I am going to unfold shortly is of course not a question of physical borders. Hence, the cue I want to take from Green is an analytical one in terms of the relation between a difference that makes a difference and a difference that does not make a difference, and the doubts, ambiguities and uncertainties involved in this relation. Moreover, I will analytically 'flip' the question of difference as put forth by Green by arguing that doubt and ambiguity may just as well arise when difference does not make a difference, that is, when societal change ceases to be seen as changing anything.

\section{Revolutionary difference}

There are few other words that symbolize the notion of 'difference' as strongly as that of 'revolution'. If anything, revolutionary hope is premised on a telos of change; an event that is expected to potentially render a given society either partly or completely different from what it was before, and a notion that has 
been central in the unfolding of politics in the modern world (Arendt 2006; Magun 2013; Scott 2014). For many, both locally and internationally, the Rose Revolution taking place in Georgia in November 2003 was initially seen as exactly this; a telos of change. As thousands of people in Tbilisi went onto the streets and eventually entered parliament, there was clear anticipation about what they wanted to be different. During the preceding twelve years of independence from the Soviet Union, the Georgian nation had been a site of civil wars, corrupt officials, infrastructural breakdowns and a political scene marked by continuous turmoil (Dudwick 2002). Moreover, not only was this revolution an apparently clear-cut break with a previous government and mode of politics, it was also seen on a larger scale (at least from the West) as symbolizing a break with the failed-state syndrome that had marked several new nations in post-Soviet Eastern Europe. Liberal democracy was finally on the rise (Frederiksen and Gotfredsen 2017), and Georgia was, at least ostensibly, to become a textbook example of developing good governance and transparency (Gotfredsen 2015).

The new government that was subsequently elected in early 2004 was led by one of the leaders of the revolution, Mikhail Saakashvili. Neither he nor his fellow government officials were shy of highlighting the significance of the revolution and the difference it represented (Frederiksen 2013; Dunn and Frederiksen 2014). The task ahead of them of course now was that they actually had to prove that this difference would really make a difference. Expectations were high, the president had given many something to hope for that now had to be turned into reality. And from the very beginning there were changes certainly being made, often quite dramatic ones. While some operated mainly on a symbolic level through iconoclastic measures such as changing street names, changing the flag and removing or substituting statues (Manning 2007; Frederiksen 2013), others were initiated through reform processes. These included alterations within sectors such as healthcare (Schecter 2011; Koch 2013), state and institution-building (Aliyev 2014), social security (Frederiksen 2014) and anti-corruption (Di Puppo 2014), to name but a few. The reform processes were measures seeking to ensure that people once again had something to hope for, that politicians and the political system could be trusted, that things were (or would be) changing for the better. All of this supported by a political rhetoric seeking to convey to the population that they no longer had to wait for the future - the future was already there, what the population had hoped for was already happening. 


\section{Everything changes while staying the same}

While (potential) change was highly visible on the surface of Georgian society traces of 'something happening' being everywhere - there were also places where nothing was happening, and there people who had increasingly grown tired of the 'something' that was going on.

It is late August 2012 and I am walking around with Vano and Paata, trying to find a place to hang out. They had been recently banned from their regular café, an ad hoc bar based in a partly demolished building in the city centre. Vano and Paata had been getting into too many fights lately, either with each other or with other guests, and the staff had grown tired of it. I had been with them on one such occasion, about six months earlier. Vano had gotten into an argument with a man who had ended up smashing a bottle on Vano's head, the latter refusing to go to the hospital with the constant claim that 'it's nothing, it's nothing' (araperia), despite him having an open wound in his neck and splinters of glass down his back.

On this day in August, we have been walking around for a good while. It is late in the afternoon and the heat is excruciating. We have had a few beers in a park, calling some people to find out whether they have a place where we can stay during the evening. Vano detests the idea of going to a regular bar or café they all have some idiotic decor, he sighs; pastiches of either 'traditional Georgia', with their brick walls, wooden furniture and polyphonic singing on the stereo, or 'some retro-Buddha-art shit'. New cafés and bars have been popping up like mushrooms in recent years, mainly in the newly renovated parts of the city's Old Town district that, in Vano's view, now looks more like a set from a Disney movie than a place where people live.

Paata calls a guy he recently met, Beqa, and we are invited to come to his place. Beqa's apartment is located in the northernmost part of the Mtatsminda neighbourhood, close to the Old Town but still a place no politician had yet thought of renovating at the time. 'A bad neighbourhood,' Vano notes while we are climbing the steep stairs to reach the door. 'A lot of crime here, and people who are crazy. But then, most of my own friends are as well.' He tells the story of how one time, while Paata was walking down Rustaveli Avenue in the city centre, a random guy had yelled 'gay' at him, maybe because of the way he dresses, and Paata had taken out a knife and cut him - not killing him, Vano says, but still causing some injury. 'He likes to cut in stuff, but you already know that', he concludes as we reach our destination. A pair of drowsy eyes partly covered by wild and messy hair appear from behind the door. Beqa lets us in. $\mathrm{He}$ 
lives here with his sister, who joins us once in a while in the evening, and a small black dog. The apartment is largely empty, with small rundown rooms. There is a couch, a few chairs and a small table in the living room, but no other furniture. A few pages from a Swedish magazine have been taped to one of the walls. I ask Beqa why they have hung them there. 'Not really for any reason', he says. None of them can read what it says. Beqa finds an assortment of small glasses in different shapes and colours and Vano takes out the vodka, soda and grape juice that we bought before coming. Cigarette packs are thrown on the table along with an ashtray and someone puts on music. The heat is still stifling and we slowly melt into our chairs, drinking without toasting, listening to music, smoking and chatting. All windows are open but there is no wind and cigarette smoke hangs still in the air.

At some late hour of the night, Paata and I begin discussing politics. Parliamentary elections are coming up. The president at this point in time is still Mikhail Saakashvili but his party United National Movement stands to loose to Georgian Dream, led by the challenger Bidzina Ivanishili. I did not know much about Ivanishvili's political standpoint but I knew Saakashvili, and had been writing about the drawbacks of his grand political visions and how they were implemented. Paata says that he is going to vote for Saakashvili. I ask him why and minor discussion starts. Paata notes that Saakashvili 'already filled his pockets', and if a new president and political party come to power 'it would not change anything anyway, just as the last change of power didn't'. Although the political scene changes, politics is as stale as the air of the room we are sitting in. There are differences but they do not make a difference. I do not think much of it: everyone discusses politics in Georgia, even though no one ever finds politics worth discussing, ${ }^{4}$ so it seems harmless. Paata gets a bit agitated at one point but the conversation soon drifts into something else. My participation ends a few hours later, not because of that particular discussion but because I, like everyone else, am getting drunk and tired. Vano wants to be sure that I make it home safely, and he has a feeling, he confides to me by dragging me slightly aside, that Paata will soon punch someone. Probably Vano himself or Beqa; they always got into fights, but I should go home before it happens. So I leave.

I did not see Paata again for almost a year, until May 2013. The first thing Paata did when we met again was to apologize. I had no idea why. 'For the discussion about politics we had last time we saw each other,' he said. I confided that although I remembered it, I had not given it much thought. Still, Paata said, he was sorry about it. He had not meant to make a point about anything I should not take it as him actually having a stance towards, or caring about, 
politics - he had just been drunk. And so we went along the street to find a place to buy a bottle we could empty. I remember thinking that this was probably the closest Paata and I had ever come to having a conversation about something that related to the socio-political context we were in. Surely, it was a conversation that negated the importance of this context, but still. I also thought that perhaps we now knew each other well enough for him to randomly punch me later that evening, as he did his other friends. But it was Paata, would it matter? I had known Vano, Paata and their friends for years, meeting with them whenever I was in Tbilisi for fieldwork. But they had never been a focus of my research. It was when Natia told me that everyone she knew was a nihilist that I had begun to think about changing this, as I knew Natia had been among their circle at one point, which meant that there was suddenly a lot of things about Vano and Paata that began to make sense. Or rather, there was a senselessness that suddenly stood forth as a potential realm worthy of inquiry. So I would return again in the spring of 2014, spending months doing nothing with Vano, Paata and their friends, only this time with their nothingness and disengagement as the focus of my work. Our time together became one of randomness, repetition, negations, sighs, seclusions, fights, lazy afternoons, weekends doing nothing, Greenaway, Morrissey, Tarkovsky, Kerouac, unintelligible conversations, and then all of it once more (Frederiksen 2016).

We were, however, not together all the time. Some had to go to work, others to their classes at university or to their art studios. During these periods I would visit other old friends in the city and the subject of my research would often come up in conversations. On one occasion I visited my former landlady Marina, who was hosting a lunch for some of her friends. There are no overfilled ashtrays here, no loud music, no fights, no sighs. Instead there are Easter decorations on the table along with an assortment of homemade traditional food. There is chatter everywhere, a moderate amount of good wine, vast amounts of laughing, joking, dessert and coffee. Sitting next to me is Marina's friend Nona who is intrigued by my interest in nothingness and nihilism. 'You know, she says, 'we're obsessed with nothing here, it's all there is, it's all we talk about.' At this point, Bidzina Ivanishvili's party had won national elections and Mikhail Saakashvili had fallen from power. But that did not seem to have changed anything, at least not from Nona's perspective. Everything was the same; there was still a lot of nothing going on.

Elizabeth Dunn has observed a similar preoccupation with the notion of 'nothing' in the Georgian IDP ${ }^{5}$ settlements in which she conducted fieldwork (Dunn 2014). Here, people would describe to her how they 'had nothing' and how 
'nothing was being done' and nothingness became, Dunn writes, a central category through which IDPs understood their lives, their relationships to the state and to the international community (Dunn 2014: 288). Despite the fact that I had initially thought nihilism to be found only in the smoke-filled rooms of my primary fieldsite, nothingness could thus not necessarily be confined to Paata, Vano and their friends; it also existed as sentiments among IDPs, and in political discussions around lunch tables. In different configurations, it seemed to somehow permeate aspects of the lives of a range of different individuals and groups in the country. It was not so surprising, then, that Natia had told me that everyone she knew was a nihilist. And Ivanishvili may thus have been right when he asserted that nihilism had become ingrained in Georgians. His problem, now after he himself became prime minister, was that the political change he had been part of initiating by talking about himself as a potential vanguard against nihilism and a new provider of hope, had not changed that situation. There had not become less of nothing.

\section{The sun shone, having no alternative, on nothing new}

There are many definitions of what nihilism is or can be. ${ }^{6}$ Here, we are not dealing with organized (or political) nihilism, but rather with displays of nihilist sentiments. For that reason I therefore follow Simon Critchley, via Nietzsche and Beckett, in seeing nihilism as a crisis of meaning and distrust in endpoints (Critchely 2004: 32). And it is particularly Beckett's work that I want to pursue here in relation to the cases from Georgia presented above. Beckett has been referred to as a poet of nothingness, often exploring the relation between waiting and nothing. David Kleinberg-Levin (2015), in examining Beckett's depictions of hope and waiting, brings our attention to the seventh book of Texts for Nothing in which the main character sits in a third-class waiting room of a railway station waiting for a train that will never come. Both here, as well as in Calmative and Krapp's Last Tape,

Beckett seems implicitly to be challenging us to consider the promise of happiness after the Death of God and the end of religion ... Our problem, our defeat, lies in waiting, waiting interminably for that great revelation, that miraculous event of messianic or utopian transformation, suddenly erupting into our world from outside, manipulating everything to make it all just right. Perhaps not today, but on the day after tomorrow (2015: 157).

This is a condition, Kleinberg-Levin notes, that is also found in the works of Franz Kafka and W. G. Sebald. In the latter's 'Dr K. Takes the Waters at Riva' 
a man among a group of townspeople, who are waiting for someone from an insurance company, notes how 'those in whom we invest our hopes only ever make their appearance when they are no longer needed' (quoted from KleinbergLevin 2015: 287). ${ }^{7}$

But perhaps the most well-known example of Beckett's writings on waiting and nothing is of course Waiting for Godot (Beckett 2011), which the critic Vivian Mercier famously depicted as a play where 'nothing happens, twice' (Green 2011: 76). Beckett was in a sense more interested in the notion of waiting than in who or what Godot is (Valentine 2009: 140). We never really learn anything about Godot in the play, the telos of those waiting remaining indistinct throughout. We might thus say that the two tramps Vladimir and Estragon are not waiting for anything specified, but for nothing in particular. In his reading of Godot and other novels, Mladen Dolar compares the writing style of Beckett to that of James Joyce. While Joyce, he notes, was interested in infinite addition $(n+1)$, Beckett was interested in the exact opposite: subtracting meaning (n-1) (Dolar 2012: 51). 'One can easily imagine,' Dolar writes, 'the two writers reading their proofs, Joyce relentlessly adding new twists, and Beckett constantly crossing out, deleting scenes, paragraphs, pages. For one there is never enough, for the other there is never little enough' (Dolar 2012: 52).

Dolar goes on to insert Beckett in another literary juxtaposition that is worth taking up here, namely differences between Beckett and Jean-Paul Sartre in their respective descriptions of picking up a stone. In Beckett's novel Molloy (2009 [1951]) the protagonist sets up a system for sucking on stones that he finds on a beach. This is a depiction, writes Dolar, that can be seen as a response to the opening scene of Sartre's Nausea (2000 [1938]) in which the protagonist equally engages in the activity of picking up stones on a beach. Yet while in Nausea only one stone is chosen, in Molloy multiple stones are picked up, and whereas Sartre's hero is disgusted by the stone to the point of becoming nauseous, Beckett's hero indulges in his own disgust, putting the stones in his mouth to explore their tastelessness (Dolar 2012: 55). Although both authors are thus interested in the question of meaninglessness ( $n-1)$, for Sartre the meaningless and its accompanying absurdity is an existential problem, whereas for Beckett it is one of indifference: 'In Sartre the stone has no meaning, its stupid being there and inertia endow the rest of existence with a stone-like quality - the stone petrifies it and turns it into absurdity, (Dolar 2012: 55). In Beckett 'all stones taste the same, they are tasteless, indifferent', so why suck one stone rather than the other? Well, the stone is the creature of minimal difference, or the difference of the same, the difference of the indistinct, and it is the "indifferent difference" that 
counts, quite literally' (Dolar 2012: 56). And so we are back to the question of difference: differences making a difference, differences not making a difference, differences that one is indifferent towards.

The tramps Vladimir and Estragon have been described by John Valentine as being nihilists in Nietzsche's precise sense of the term: 'a nihilist is not one who believes in nothing, but one who abandons belief in this world in favour of another world that is (according to Nietzsche) idealized, fictitious, and the product of the mechanism of ressentiment' (Valentine 2009: 138; emphasis in original). Dolar comes to a slightly different conclusion in his juxtaposition of Beckett against Joyce and Sartre, which highlights Beckett's constant deduction of meaning alongside descriptions of indifference towards this meaninglessness. Here, the nihilist tendency is, similarly to Valentine's observation, not an insistence on complete nothingness, but rather (and here he departs somewhat from Valentine) a gravitation away from something and towards nothing (see also Pilling 2010: 21).

\section{Waiting for something to wait for, or waiting for nothing to change}

How may we relate such gravitation towards nothing to the question of waiting? In much anthropology theorizing, waiting has been related to the question of hope - a gravitation towards something. As Mathijs Pelkmans has argued, 'even in the direst situations people will find new points of orientation and aspiration' (Pelkmans 2013: 3). Recent studies have furthermore linked the notion of hopefulness to questions of reciprocity and giftgiving (e.g. Hage 2003; Miyazaki 2004). Ghassan Hage has noted how a state's ability to distribute hope, for instance through the creation of particular places or scenarios, is a vital part of what makes a population trust the state. Hage describes this as 'social gifts' that enables a population to see themselves as part of a society's future (Hage 2003: 10, 146; see also Frederiksen 2013: 154ff.). Of central importance in this relation is of course that the recipient actually wants to receive this gift of hope. If not, it is simply left floating. The fact that social change rarely (if ever) takes place overnight is a delicate issue for people who have come into power due to a promise of change and a rhetoric of hope. ${ }^{8}$ The lack of immediate change following political promises may themselves easily translate into doubt, passivity and apathy (Bartha 2013: 220), as people loose their belief in the promises given and start waiting doubtfully for a change to come (Jansen 2015: 180). 
But these perspectives still imply that waiting is related to something, it is 'not wholly purposeless' (Jeffrey 2010: 4), and that it is a waiting out of something perceived to have an eventual endpoint (Hage 2009). Waiting has a telos - there is something to wait for (or through), a horizon that creates a meantime (Sharma 2014: 52).

Stanley Cavell (2002) observes in relation to Beckett's engagement with waiting without a telos that:

suspense is for Hitchcock what faith is for the Christian, an ultimate metaphysical category, directing life's journey and making the universe come clear, and clean at the end. The overwhelming question for both is: How will the truth come out at last? Beckett's couples have discovered the final plot: that there is no plot, that the truth has come out, that this is the end. But they would be mad to believe it and they cannot, being human, fully give up suspense. So they wait. Not for something, for they know there is nothing to wait for. So they try not to wait, but they do not know how to end (2002: 132; emphasis in original).

And moreover that 'solitude, emptiness, nothingness, meaninglessness, silence - these are not the givens of Beckett's characters but their goal, their new heroic undertaking' (2002: 156). ${ }^{9}$ So we arrive at a central juxtaposition between the assertion that 'there is nothing here after which something will follow' (whether eschatology, teleology or utopianism) and 'there is something here of which nothing will come. To reiterate from the previous section, in Sartre's Nausea we see in the main character an acknowledgement of the existence of meaninglessness in the modern world, or rather as a result of the modern world. Eventually he comes to understand his own nausea and in this there is something to move on from (Toohey 2011: 126). With Beckett there is no such movement, only continuous waiting.

As Michael Flaherty has argued, people often find ways of 'filling in the otherwise "empty" intervals that stretch between what we have and what we want' (Flaherty 2011: 26). But the problem arises when there is nothing to wait for, but one is still waiting. Here we are not dealing with a question of existential doubt (as in Sartre) or a quest to add something different or more (as in Joyce), but of an acceptance of indifference. ${ }^{10}$ Waiting in the empirical context outlined previously, then, is not a question of uncertainty or doubt, but actually one of relative certainty; not doubting that difference might or might not make a difference but feeling certain that it will not. Not only that something will not happen, but that nothing will happen, leaving nothing the only thing to wait for. This kind of gravitation towards nothing is not something devoid of pleasure, as Beckett showed in many of his works (Weller 2010: 111). And indeed, a lot may 
be happening while nothing is happening; people have Easter lunch, or listen to music, or walk around, or get into fights. The defining feature is that all of this is going on in a context where things are being regarded as nothing, whether it be political reforms or having a bottle of vodka smashed against one's head, where there is a distrust in end-points and a crisis of meaning, where there is no point in getting so drunk that you begin to discuss politics because politics never makes a point.

A local friend had previously noted to me how Georgia was an REM-State; a place of rapid-eye-movement where 'everything is changing and still staying the same' (Frederiksen 2014: 320). She herself was from an IDP family and was, in her own words, 'waiting indefinitely' to return to her home in the Autonomous Republic Abkhazia, from where her family had fled in the mid-1990s. But due to the political stalemate in the conflict between Georgia and Abkhazia she was sure that this return would never happen, that nothing would ever change, yet she still waited for it. Returning to the border dispute between Greece and Turkey described by Sarah Green, we may thus say that in Georgia too we find an overlap of competing epistemologies coexisting within the same space: a political one claiming that changes are taking place that are creating changes differences that make a difference whether now or in the future - and a societal one claiming that changes are taking place without these actually changing anything either now or in the future, differences not making a difference. Returning also to Mladen Dolar, we may further say that in waiting for nothing to change the only change or difference possible is that of nothing itself changing (Dolar 2012: 61).

\section{Nothing more}

He who has waited long enough will wait forever. And there comes the hour when nothing more can happen and all is ended but the waiting that knows itself in vain, Samuel Beckett, Malone Dies (quoted from Kleinberg-Levin 2015).

For Nietzsche, nihilism was epitomized by the death of God - the devaluation of the highest value (Vattimo 1991: 20). As mentioned in the introduction, the value devalued in the setting described here is not necessarily that of religion, of the Orthodox Church. Rather, it is the value of political change. It is the value, we might say, of utopian ideas and visions that have been prevalent in Georgian politics both during the Soviet period in the shape of a proclaimed socialist path to a communist future and during the post-revolutionary period in the shape 
of neo-liberal ideals underpinning a perceived path to a country freed from post-Soviet turmoil. Although highly different in terms of political content, these political visions have both featured idealized versions of a grand future, a glorious end-point (Frederiksen and Gotfredsen 2017). And both end-points alike have, at different times in history, for some parts of the population ended up garnering distrust rather than hope.

In a context such as the one depicted here, the legal outcome of the attack at Campus Studio described in the introduction is almost predictable. Despite the severeness of the attack, no one was sentenced; nothing happened. There may well have been nihilists among the students, artists and architects at Campus Studio who were attacked for reading Nietzsche. Or they may just have been people who liked reading. And if the aim of the attackers was to strike down on nihilist sentiments, they might as well have gone to a random luncheon where a group of middle-aged women were discussing politics. The latter were not in any way against the Georgian Orthodox Church but they certainly believed that nothing existed. But there are of course central differences between the two. While (if that had been the point) the reading of Nietzsche and discussing his texts via loudspeakers is a public demonstration of one's belief in nihilism - a clear declaration of nothing - the discussions among Marina's friends and the doing of nothing among Vano and Paata's crowd is a much more private affair. None of them are engaging, but rather gravitating towards nothing. They are not really waiting for anything specific. As with Beckett's Estragon and Vladimir, there is no Godot, there is no telos, there is nothing beyond nothing - it does not matter which stone one picks up to suck as they are all tasteless, it does not matter that one has a piece of glass stuck in one's neck, or who is or becomes president - neither will make a difference anyway. If actual difference is ever to come around, it is the nothingness itself that will need to change, as the 'somethingness' has proved unable to.

\section{Acknowledgements}

Fieldwork for this chapter was made possible through grants from The Danish Council for Independent Research: Culture and Communication and the Sapere Aude Research Talent Programme. I owe my thanks to Katharina Stadler, Andreas Bandak and Manpreet Kaur Janeja for their valuable comments on an early draft of this paper. 


\section{Notes}

1 From Father Basil Mkalavishvili's organized assaults on religious minorities such as Jehova's Witnesses, Baptists and Evangelists to the anti-gay rally in 2013 that saw priests and supporters alike violently attacking a group of gay-rights activists, causing serious injuries. Patriarch Ilia II had the night before the latter event called homosexuality 'an anomaly and disease' and later refused to condemn the behaviour of the priests (Peuch 2005; Antelava 2013).

2 In Georgian, adamiani ar aris means literally 'is not a human' or 'un-human'.

3 The revolution had started in relation to accusations of ballot fraud during an election, as well as general accusations of corruption within the government of then-President Eduard Shevardnadze (see Manning 2007; Frederiksen and Gotfredsen 2017).

4 See Gotfredsen (2015) for a series of examples.

5 Internally Displaced Persons. Since the gaining of independence in 1991 several waves of IDPs from the civil wars in Abkhazia and South Ossetia have been living in Georgia, with a new wave having been created in 2008 during the war with Russia in South Ossetia.

6 See for instance Carr 1992; Cunningham 2002; Weller 2008; Diken 2009.

7 'Dr K. Takes the Waters at Riva' is part three of the four-part novel Vertigo in which Kafka appears as the character Dr K. (Sebald 2000).

8 In this respect, the post-revolutionary rhetoric of change put forth by Mikhail Saakashvili and the subsequent scepticism he faced from Georgian citizens differs little from Barrack Obama's presidency in the US. He too was elected as an icon of hope and soon faced the difficulties of meeting expectations he himself had created.

9 One might argue here that this places Beckett within the nihilist paradox that the absence of meaning is always some sort of meaning. Devenney (2001) notes how 'Beckett's art is an art that asprires to be ever less, in the extreme to be nothing - "only just almost never" an art of zero' (2001: 146). In this resides the paradox that a play, a short story or a novel is always in some sense something - there are pages, titles and words. As Devenney goes on to show, Beckett was well aware of this and himself, writing:

in the 'Texts for Nothing' Beckett will suggest a simlar paradox: 'all you have to do is say you said nothing and so say nothing again'. The point ... is that even when saying nothing it must all in the end be something, if only because it was said in the first place, and the only recourse is to say nothing, and then say it again, and again, because nothing, inanity can always be transformed into something. In Waiting for Godot Didi remarks 'this is all becoming really insignificant' to which Gogo responds, 'Not enough'. (2001: 146-147)

10 For a similar situation, see Michael Herzfeld's classic study on how bureaucracy was established to secure accountability but often ends up creating the opposite in reality, namely indifference (Herzfeld 1992). 


\section{References}

Aliyev, Huseyn. 2014. 'The Effects of the Saakashvili Reforms on Informal Practices in the Republic of Georgia'. Studies in Transition States and Societies 6(1): 19-33.

Antelava, Natalia. 2013. 'What Was Behind Georgia's Anti-Gay Rally?' New Yorker, 23 May 2013.

Arendt, Hannah. 2006. On Revolution. London: Penguin Classics.

Barrow, John D. 2001. The Book of Nothing. London: Vintage Books.

Bartha, Eszter. 2013. "Something Went Wrong with this Capitalism": Illusion and Doubt in a Hungarian (Post-)Industrial Community'. In Ethnographies of Doubt Faith and Uncertainty in Contemporary Societies, edited by Mathijs Pelkmans, 191-225. London and New York: I.B.Taurus.

Beckett, Samuel. 2009. Three Novels: Molloy, Malone Dies, The Unnamable. New York: Grove Press.

Beckett, Samuel. 2011. Waiting for Godot - A Tragicomedy in Two Acts. New York: Grove Press.

Carr, Karen. 1992. The Banalization of Nihilism - Twentieth-Century Responses to Meaninglessness. New York: State University of New York Press.

Cavell, Stanley. 2002 [1969] Must We Mean What We Say? - A Book of Essays.

Cambridge: Cambridge University Press.

Chigoev, Ruslan. 2011. 'Household Issues Ruin Georgian Democracy'. GeorgiaTimes, 24 October 2011.

Concept and Theory Tbilisi. 2015. 'In Support of Campus Studio, Tbilisi'. 27 November 2015, www.conceptandtheory-tbilisi.com (accessed 5 January 2016).

Critchley, Simon. 2004. Very Little ... Almost Nothing - Death, Philosophy, Literature. 2nd edition. London and New York: Routledge.

Cunningham, Conor. 2002. Genealogy of Nihilism. London: Routledge.

Dalsgaard, Anne Line and Martin Demant Frederiksen. 2013. 'Out of Conclusion - On Recurrence and Open-endedness in Life and Analysis'. Social Analysis 57(1): 50-63.

Devenney, Christopher. 2001. 'What Remains?' In Engagement and Difference - Beckett and the Political, edited by Henry Sussman and Christopher Dennevey. Albany: State University of New York Press.

Diken, Bülent. 2009. Nihilism. London and New York: Routledge.

Di Puppo, Lili. 2014. 'The Construction of Success in Anti-Corruption Activity in Georgia'. East European Politics 30(1): 105-122.

Dolar, Mladen. 2012. 'Nothing has Changed'. In Beckett and Nothing: Trying to Understand Beckett, edited by Daniela Caselli, 48-65. Manchester: Manchester University Press.

Doward, Jamie. 2011. 'I'm Not a Spy or an Oligarch, Says Georgia’s Secretive Billionaire' The Guardian, 3 December 2011, http://www.theguardian.com/world/2011/dec/03/ bidzina-ivanishvili-georgia-secretive-billionaire (accessed 12 January 2016).

Dudwick, Nora. 2002. 'No Guests at Our Table: Social Fragmentation in Georgia'. In When Things Fall Apart - Qualitative Studies of Poverty in the Former Soviet 
Union, edited by Nora Dudwick, Elizabeth Gomart and Alexandre Marc, 213-257. Washington: The World Bank.

Dunn, Elizabeth C. 2014. 'Humanitarianism, Displacement and the Politics of Nothing in Postwar Georgia.' Slavic Review 73(2): 287-307.

Dunn, Elizabeth C. and Martin Demant Frederiksen. 2014. 'Introduction'. Slavic Review 73(2): 241-245.

Flaherty, Michael G. 2011. Textures of Time - Agency and Temporal Experience. Philadelphia: Temple University Press.

Frederiksen, Martin Demant. 2013. Young Men, Time and Boredom in the Republic of Georgia. Philadelphia: Temple University Press.

Frederiksen, Martin Demant. 2014. 'The Would-Be State: Reforms, NGOs and Absent Presents in Postrevolutionary Georgia'. Slavic Review 73(2): 307-321.

Frederiksen, Martin Demant. 2015. 'De Umenneskelige - Ateisme, Meningsløshed og Subjektivitet i Georgien'. Nordisk Oestforum 29(1): 57-79.

Frederiksen, Martin Demant. 2016. 'Consciouss Sedation'. In A Consciouss Issue, edited by Katharina Stadler and Martin Demant Frederiksen. Vol. 4 of A ... Issue. Tbilisi: Favourite.

Frederiksen, Martin Demant and Katrine B. Gotfredsen. 2017. Georgian Portraits Essays on the Afterlives of a Revolution. London: Zero Books.

Gotfredsen, Katrine. 2015. 'Invisible Connections: On Uncertainty and the (Re)Production of Opaque Politics in the Republic of Georgia. In Ethnographies of Grey Zones in Eastern Europe: Borders, Relations and Invisibilities, edited by Ida Harboe Knudsen and Martin Demant Fredriksen, 125-141. London: Anthem Press.

Green, Ronald. 2011. Nothing Matters - A Book about Nothing. Winchester and Washington: iff books.

Green, Sarah. 2015. 'Making Grey Zones at the European Peripheries'. In Ethnographies of Grey Zones in Eastern Europe: Borders, Relations and Invisibilities, edited by Ida Harboe Knudsen and Martin Demant Fredriksen, 173-187. London: Anthem Press. Hage, Ghassan. 2003. Against Paranoid Nationalism: Searching for Hope in a Shrinking Society. Sydney: Pluto Press.

Hage, Ghassan. 2009. 'Waiting Out the Crisis: On Stuckedness and Governmentality'. In Waiting, edited by Ghassan Hage, 97-106. Melbourne: Melbourne University Press. Herzfeld, Michael. 1992. The Social Production of Indifference - Exploring the Symbolic Roots of Western Bureaucracy. Chicago: Chicago University Press.

Jansen, Stef. 2015. Yearnings in the Meantime - 'Normal Lives' and the State in a Sarajevo Apartment Complex. New York and Oxford: Berghahn Books.

Jeffrey, Craig. 2010. Timepass - Youth, Class, and the Politics of Waiting in India. Stanford, CA: Stanford University Press.

Johnson-Hanks, Jennifer. 2014. 'Waiting for the Start: Flexibility and the Question of Convergence'. In Ethnographies of Youth and Temporality: Time Objectified, edited by Anne Line Dalsgaard, Martin Demant Frederiksen, Susanne Højlund and Lotte Meinert, 23-40. Philadelphia: Temple University Press. 
Kleinberg-Levin, David. 2015. Beckett's Words: The Promise of Happiness in a Time of Mourning. London: Bloomsbury Academic.

Koch, Erin. 2013. Free Market Tuberculosis - Managing Epidemics in Post-Soviet

Georgia. Nashville, TN: Vanderbilt University Press.

Magun, Artemy. 2013. Negative Revolution - Modern Political Subject and its Fate after the Cold War. New York: Bloomsbury.

Manning, Paul. 2007. 'Rose Colored Glasses? Color Revolutions and Cartoon Chaos in Postsocialist Georgia. Cultural Anthropology 22(2): 171-213.

Miyazaki, Hirokazu. 2004. The Method of Hope - Anthropology, Philosophy, and Fijian Knowledge. Stanford, CA: Stanford University Press

Pelkmans, Mathijs. 2013. 'Outline for an Ethnography of Doubt'. In Ethnographies of Doubt - Faith and Uncertainty in Contemporary Society, edited by Mathijs Pelkmans, 1-43. London and New York: I.B. Tauris.

Peuch, Jean-Christophe. 2005. 'Georgia: Defrocked Priest Sentenced for Religious Violence'. RadioFreeEurope, 1 February 2005.

Pilling, John. 2010. 'On Not Being There: Going on Without Beckett'. In Beckett and Nothing: Trying to Understand Beckett, edited by Daniela Caselli, 20-28. Manchester: Manchester University Press, .

Sartre, Jean Paul. 2000. Nausea. London: Penguin Books.

Sebald, Winfried Georg. 2000. Vertigo. New York: New Directions Books.

Schecter, Kate. 2011. 'The Privatization of the Georgian Healthcare System'. Anthropology of East Europe Review 29(1): 16-22.

Scott, David. 2014. Omens of Adversity - Tragedy, Time, Memory, Justice. Durham, NC, and London: Duke University Press.

Sharma, Sasha. 2014. In the Meantime - Temporality and Cultural Politics. Durham, NC, and London: Duke University Press.

Toohey, Peter. 2011. Boredom - A Lively History. New Haven, CT, and London: Yale University Press.

Valentine, John. 2009. 'Nihilism and the Eschaton in Samuel Beckett's Waiting for Godot'. Florida Philosophical Review IX(2): 136-147.

Vattimo, Gianni. 1991. The End of Modernity. Cambridge: Polity Press.

Weller, Shane. 2008. Literature, Philosophy, Nihilism. The Uncanniest of Guests. Basingstoke: Palgrave Macmillan.

Weller, Shane. 2010. 'Unwords'. In Beckett and Nothing: Trying to Understand Beckett, edited by Daniela Caselli, 107-125. Manchester: Manchester University Press. 